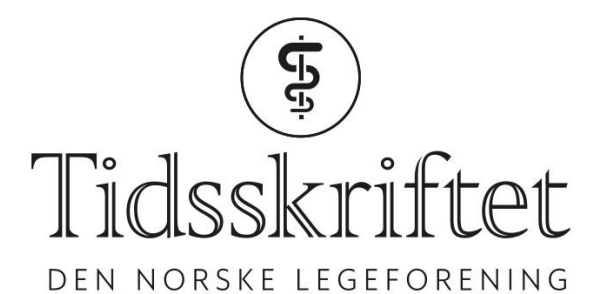

DEN NORSKE LEGEFORENING

\title{
Kan miljøgifter true oss som art?
}

DEBATT

\section{JAN BROX}

E-post: jan.brox@unn.no

Jan Brox er ph.d., spesialist i medisinsk biokjemi og overlege ved Avdeling for laboratoriemedisin, Universitetssykehuset Nord-Norge.

Forfatteren har fylt ut ICMJE-skjemaet og oppgir ingen interessekonflikter.

\section{MARIA AVERINA}

Maria Averina er ph.d., spesialist i medisinsk biokjemi og overlege ved Avdeling for laboratoriemedisin, Universitetssykehuset Nord-Norge.

Forfatteren har fylt ut ICMJE-skjemaet og oppgir ingen interessekonflikter.

\section{SANDRA HUBER}

Sandra Huber er ph.d. og seniorkonsulent ved Avdeling for laboratoriemedisin, Universitetssykehuset Nord-Norge.

Forfatteren har fylt ut ICMJE-skjemaet og oppgir ingen interessekonflikter.

Stoffer som virker som hormonhermere, finnes både i vårt økosystem og i vår egen organisme. De har svært uheldige virkninger.

Miljøgifter er en samlebetegnelse på mange ulike stoffer som finnes i miljøet. De hoper seg opp på grunn av lang nedbrytningstid, finnes i dyr og mennesker og har/ kan ha sykdomsfremkallende effekt.

Vi kan dele disse inn i "gamle» og i dag forbudte, organiske miljøgifter som diklordifenyltrikloretan (DDT) og polyklorerte bifenyler (PCB), og «nye» organiske miljøgifter som ftalater (plastmykgjørere), bromerte flammehemmere, parabener og perfluorerte alkylstoffer (PFAS) som finnes blant annet i «superglatt» skismurning.

Disse miljøgiftene finnes i vårt hverdagsmiljø - også i maten - og eksponering for disse er en helserisiko (1).

Flere av de organiske miljøgiftene kan med en samlebetegnelse kalles hormonhermere, idet de blant annet har østrogenlignede effekter, men de kan også interferere med tyroksinvirkningen i fosterlivet. Nordisk ministerråd har utarbeidet en rapport om miljøgifter i mennesker, som anslår at human eksponering for perfluorerte alkylstoffer er ansvarlig for tap av 750-1 250 menneskeliv årlig i Norden (2). Videre vurderer de at disse stoffene gjør at i hvert fall 130 nordiske babyer fødes undervektige hvert år. De estimerer at de nordiske landene bruker 21-35 milliarder danske kroner per år for å motvirke helseproblemene og overdødeligheten som stoffene skaper. 


\section{Hvilke biologiske effekter ser man?}

Det er først og fremst i fosterlivet at miljøgiftene kan være skadelige.

Man har funnet redusert motorisk utvikling hos spedbarn hvor mødrene har høyt nivå av organiske miljøgifter i svangerskapet (3). Man finner også redusert IQ hos barn og en dramatisk reduksjon av spermiefunksjon hos unge menn som relateres til eksponering for miljøgifter i fosterlivet $(4,5)$.

I Troms $\emptyset$ har vi sett at ungdommer med høye blodnivåer av perfluorerte alkylstoffer har økt risiko for å utvikle astma og nikkelallergi (6).

I rapporten fra Nordisk ministerråd påpekes det at eksponering kan føre til redusert immunrespons, $\varnothing \mathrm{kt}$ risiko for brystkreftutvikling, kronisk nyresykdom, fedmeutvikling og ADHD hos barn. En studie fra Nordvest-Russland viser at miljøgifter i morens blod påvirker lengde og vekt av nyfødte (7).

Vi vet at miljøgiftene har skadelige effekter på mennesker

Miljøgifter generert i industrialiserte land, som for eksempel land i Asia, transporteres med luft- og havstrømmer og akkumuleres i Arktis. Dermed er det spesielt aktuelt å forske på forekomst og effekter av miljøgifter i nordområdene. Ved Miljøgiftlaboratoriet, Universitetssykehuset Nord-Norge (UNN), har vi gjennom flere år analysert ulike organiske miljøgifter i humane prøver. Vi har funnet betydelig høyere nivåer av hormonhermende miljøgifter enn ordinære kjønnshormoner i blodet hos klinisk friske mennesker (6). I en multisenterstudie av norske friske blodgivere fra tre ulike regioner i Norge analysert ved Miljøgiftlaboratoriet, Universitetssykehuset Nord-Norge og ved Laboratorieklinikken ved Haukeland universitetssjukehus, ble det påvist at $18 \%$ av blodgivere hadde for høyt nivå av bly, $11 \%$ hadde for høyt nivå av kvikksølv og $100 \%$ hadde for høyt nivå av perfluorerte alkylstoffer (8). For høyt nivå hos blodgivere ble estimert ut fra risiko ved blodtransfusjoner til nyfødte.

Vi vet at miljøgiftene har skadelige effekter på mennesker, blant annet på spermiefunksjon, fosterutvikling, naturlige hormoner, immunrespons, lipidmetabolismen og sentralnervesystemet. Den samlede helseskadelige effekten av de mange ulike organiske og uorganiske miljøgiftene som vi har i blodet samtidig, er ikke kjent. Tidligere har analyseteknologien vært en begrensende faktor i miljøgiftforskning. I dag har vi sensitive massespektrometriske metoder som tillater oss å måle et stort repertoar av miljøgifter, med god kvalitet og god kapasitet. Dette åpner nye muligheter for forskning.

\section{LITTERATUR:}

1. Knutsen HK, Alexander J, Barregård L et al. Risk of human health related to the presence of perfluorooctane sulfonic and perfluorooctanoic acid in food. EFSA J 2018; 16 : 5194.

2. Goldenman G, Fernandes M, Holland M et al. The cost of inaction. A sosioeconomic analysis of environmental and health impacts linked to exposure to PFAS. København: Nordisk Ministerråd, 2019: 191. http://norden.diva-portal.org/smash/record.jsf?piddiva2\%3A1295959\&dswid=1869 Lest 22.5.2020.

3. Bjerregaard-Olesen C, Bach CC, Long M et al. Associations of fetal growth outcomes with measures of the combined Xenoestrogenic activity of maternal serum perfluorinated alkyl acids in Danish pregnant women. Environ Health Perspect 2019; 127: 17006. [PubMed][CrossRef]

4. Stewart PW, Lonky E, Reihman J et al. The relationship between prenatal PCB exposure and intelligence (IQ) in 9-year-old children. Environ Health Perspect 2008; 116: 1416-22.

[PubMed][CrossRef]

5. Di Nisio A, Sabovic I, Valente U et al. Endocrine disruption of androgenic activity by fluoroalkyl substances: clinical and experimental evidence. J Clin Endocrinol Metab 2019; 104: 1259-71. [PubMed][CrossRef]

6. Averina M, Brox J, Huber S et al. Serum perfluoroalkyl substances (PFAS) and risk of asthma and 
various allergies in adolescents. The Tromsø study Fit Futures in Northern Norway. Environ Res 2019; 169: 114-21. [PubMed][CrossRef]

7. Bravo N, Grimalt JO, Chashchin M et al. Drivers of maternal accumulation of organohalogen pollutants in Arctic areas (Chukotka, Russia) and 4,4'-DDT effects on the newborns. Environ Int 2019; 124: 541-52. [PubMed][CrossRef]

8. Averina M, Hervig T, Huber S et al. Environmental pollutants in blood donors: The multicentre Norwegian donor study. Transfus Med 2020;30: tme.12662. [PubMed][CrossRef]

Publisert: 24. juni 2020. Tidsskr Nor Legeforen. DOI: 10.4045/tidsskr.20.0392

Mottatt 5.5.2020, første revisjon innsendt 19.5.2020, godkjent 22.5.2020.

(C) Tidsskrift for Den norske legeforening 2020. Lastet ned fra tidsskriftet.no 